\title{
Effects of glucagon-like peptide 1 on appetite and body weight: focus on the CNS
}

\author{
L van Bloemendaal", J S ten Kulve*, S E la Fleur ${ }^{1}$, R G ljzerman and M Diamant \\ Diabetes Centre, VU University Medical Centre, PO Box 7057, 1007 MB Amsterdam, The Netherlands \\ ${ }^{1}$ Department of Endocrinology and Metabolism, Academic Medical Centre, University of Amsterdam, Amsterdam, \\ The Netherlands \\ *( L van Bloemendaal and J S ten Kulve contributed equally to this work)
}

Correspondence should be addressed to $L$ van Bloemendaal Email

I.vanbloemendaal@vumc.nl

\begin{abstract}
The delivery of nutrients to the gastrointestinal tract after food ingestion activates the secretion of several gut-derived mediators, including the incretin hormone glucagon-like peptide 1 (GLP-1). GLP-1 receptor agonists (GLP-1RA), such as exenatide and liraglutide, are currently employed successfully in the treatment of patients with type 2 diabetes mellitus. GLP-1RA improve glycaemic control and stimulate satiety, leading to reductions in food intake and body weight. Besides gastric distension and peripheral vagal nerve activation, GLP-1RA induce satiety by influencing brain regions involved in the regulation of feeding, and several routes of action have been proposed. This review summarises the evidence for a physiological role of GLP-1 in the central regulation of feeding behaviour and the different routes of action involved. Also, we provide an overview of presently available data on pharmacological stimulation of GLP-1 pathways leading to alterations in CNS activity, reductions in food intake and weight loss.
\end{abstract}

\author{
Key Words \\ - glucagon-like peptide 1 \\ - CNS \\ - feeding behaviour \\ - obesity \\ - type 2 diabetes
}

Journal of Endocrinology (2014) 221, T1-T16

\section{Introduction}

Obesity and type 2 diabetes mellitus (T2DM), also termed 'diabesity', are major public health problems due to their pandemic occurrence (Whiting et al. 2011, Flegal et al. 2012) and their association with adverse consequences, such as cardiovascular disease and cancer (Stratton et al. 2000, Field et al. 2001). Obesity is the result of a long-term positive energy balance whereby energy intake surpasses expenditure. The CNS plays a major role in the maintenance of body weight and energy balance within a narrow range by regulating energy intake and energy expenditure. To regulate energy intake, signals, both neuronal and humoral, arising from peripheral organs involved in food intake, - digestion and - storage, such as the gut, pancreas, and adipose tissue, convey information on hunger and/or satiety to the brain. Gut-derived hormones, such as the orexigenic hormone ghrelin and the prandially secreted anorexigenic hormones cholecystokinin (CCK), peptide YY (PYY), oxyntomodulin (OXM) and glucagon-like peptide 1 (GLP-1), have been identified as players in the regulation of feeding by relaying meal-related information on nutritional status to the brain.

Based on more than three decades of experimental evidence from rodent models and humans, GLP-1 was shown to lower blood glucose by stimulating insulin secretion and production and suppressing glucagon secretion in a glucose-dependent manner. Also GLP-1 decelerates gastric emptying, reduces body weight and induces satiety (Holst 2007). As native GLP-1 is quickly inactivated by the ubiquitous enzyme dipeptidyl peptidase 4 (DPP-4), requiring continuous parenteral 
administration, degradation-resistant GLP-1 receptor agonists (GLP-1RA) have been developed that can be injected s.c. once daily (QD) or twice daily (BID) or even once weekly (QW) (Fineman et al. 2012). These agents are currently successfully being employed in the treatment of T2DM (Drucker \& Nauck 2006). GLP-1RA improves glycaemic control and stimulates satiety, leading to reductions in food intake and body weight. The presence of GLP-1 receptors in the CNS and findings from animal and human studies indicate that the GLP-1RA-induced satiety and weight effects may be, at least in part, mediated by their actions on the brain. This review focuses on current evidence for a physiological role of GLP-1 in the central regulation of feeding behaviour. Also, we provide an overview of presently available data on pharmacological stimulation of GLP-1 pathways leading to CNS activation, changes in food intake and weight loss.

\section{CNS regulation of feeding}

Food intake is regulated by complex interactions between nutrients, hormones, neuropeptides and several different brain areas. The regulation of feeding can be divided in homeostatic and non-homeostatic feeding (Lutter \& Nestler 2009). Homeostatic feeding controls energy balance by adjusting food intake to promote stability in the amount of energy stores. However, non-homeostatic or hedonic feeding can override this homeostatic pathway resulting in overeating. It has been postulated that this is caused by the rewarding (palatable) properties of food (Wang et al. 2004, Volkow \& Wise 2005, Trinko et al. 2007).

Homeostatic control of feeding consists of the sensing and integration within the CNS of changes in nutrients, hormones and neuropeptides, reflecting changes in energy balance and the ensuing alterations in food intake. The brainstem and hypothalamus are important CNS structures within the regulatory pathways of homeostatic feeding as they receive, convey and integrate peripheral signals. The area postrema (AP) and nucleus tractus solitarii (NTS) in the brainstem convey these peripheral signals, consisting of nutrients, hormones and vagal afferent activation, to the arcuate nucleus (ARC) of the hypothalamus (Bailey 2008). The ARC consists of orexigenic neurons (expressing neuropeptide $\mathrm{Y}$ and agoutirelated peptide) and anorexigenic neurons (expressing pro-opiomelanocortin), which collectively regulate homeostatic control of eating (Gao \& Horvath 2008). In this process, the hypothalamus acts as a gatekeeper, as it additionally controls body temperature, energy expenditure and glucose metabolism. In normal physiology, the integration of all peripheral signals will result in energy intake matching the organism's energy expenditure.

The homeostatic signals arising from peripheral organs convey different aspects of the energy regulatory process to the CNS: long-term ('static') information about energy stores and acute, meal-related ('dynamic') information (Schwartz et al. 2000, Havel 2001). Adipose-tissuederived leptin, which is secreted in proportion to adipose mass, conveys 'static' information to the CNS about longterm energy stores. In normal physiology, central leptin signalling has an anorectic effect (Cohen et al. 2001), and central leptin resistance has been postulated to be a contributing factor to the development of obesity (Considine et al. 1996, Levin \& Dunn-Meynell 2002, Enriori et al. 2007). Insulin secreted from pancreatic $\beta$-cells displays both tonic (basic) $24 \mathrm{~h}$ and meal-related secretion (Polonsky et al. 1988). Thus, insulin may relay both long-term and acute information and was shown to act in the brain to reduce food intake (Woods et al. 1979, Bruning et al. 2000, Benedict et al. 2008). In obesity and over-nutrition, peripheral insulin resistance results in chronic hyperinsulinaemia. Interestingly, a study using 18-fluoro-deoxy-glucose $\left({ }^{18} \mathrm{FDG}\right)$ positron-emission tomography (PET) indicated the existence of central insulin resistance in obese individuals with the metabolic syndrome, which is compatible with the generally greater caloric intake in these individuals (Anthony et al. 2006). The above-mentioned meal-related gut-derived hormones (ghrelin, CCK, PYY, OXM and GLP-1) signal dynamic information about the changes in nutritional status to the CNS.

In contrast to homeostatic control of feeding behaviour, non-homeostatic feeding behaviour is not regulated by hunger and satiety signals but rather by the rewarding properties and motivation related to foods, and involves reward, cognitive and emotional factors. Thus, corticolimbic circuits in humans (including the striatum, amygdala, insula, nucleus accumbens (NAc) and orbitofrontal cortex) are implicated in non-homeostatic eating. Within the CNS, pathways for homeostatic and nonhomeostatic control of feeding comprise multiple interconnected brain regions. The above-described hormonal regulators of homeostatic feeding may also influence brain reward systems and may increase or decrease the rewarding value of food depending on energy requirements (Berthoud 2011, Kenny 2011). Palatable food can activate brain reward circuits, and these rewarding effects can be a

Published by Bioscientifica Ltd 
powerful motivation for food consumption and may overrule signals regulating homeostatic feeding.

The studies summarised above show that both homeostatic and non-homeostatic factors influence feeding behaviour and that there is an extensive crossmodulation of signals within these pathways. Leptin and gut-derived hormones have been studied in the search for therapeutic targets for the treatment of obesity, but these attempts were not successful (Crawley \& Beinfeld 1983, Jordan et al. 2008, Costantini et al. 2011, Moon et al. 2011, Cummings 2013), except for GLP-1RA. Although not approved for the treatment of obesity, administration of GLP-1RA consistently results in body weight loss in humans.

\section{GLP-1RA treatment and body weight in humans}

\section{The incretin system: from physiology to pharmacology}

Following meal ingestion, GLP-1 is secreted into the circulation by enteroendocrine L-cells located in the distal jejunum and ileum and contributes to postprandial glucose regulation, as it augments meal-related insulin secretion from the pancreas (Kreymann et al. 1987, Mojsov et al. 1987). Also GLP-1 promotes insulin gene transcription (Drucker et al. 1987). Also, GLP-1 improves pancreatic $\beta$-cell glucose responsiveness (Holz et al. 1993). Other glucose-lowering mechanisms of GLP-1 involve inhibition of glucagon secretion and deceleration of gastric emptying and gut motility. In addition to pancreatic islets, GLP-1 receptors have been demonstrated in the gut, heart, vasculature, kidney, muscle and lung (Sivertsen et al. 2012), indicting so-called pleiotropic effects of GLP-1, i.e. effects beyond glucose lowering. Many excellent reviews have been published describing the physiological role of GLP-1 in glucose regulation and the pleiotropic effects (Baggio \& Drucker 2004, Drucker 2006, Holst 2007, van Genugten et al. 2009, Vilsboll \& Garber 2012).

Exenatide, the first GLP-1RA developed for human use, is a synthetic form of exendin-4, a 39-amino acid peptide isolated from the salivary secretions of the Gila monster (Heloderma suspectum). Exendin-4 shares 53\% sequence identity with GLP-1. Substitution of alanine by glycine at the second position of the $\mathrm{NH}_{2}$-terminus makes exendin-4 resistant to DPP-4-mediated degradation (Nielsen et al. 2004). Exendin-4 has greater effective receptor affinity than native GLP-1 and is therefore a potent GLP-1RA (Raufman et al. 1992, Young et al. 1999).
Exenatide is currently available in two formulations for the treatment of T2DM, i.e. a short-acting compound for BID s.c. injection (half-life $2.4 \mathrm{~h}$, to be administered before breakfast and dinner) and a long-acting extended-release formulation for QW administration. Exenatide BID was approved by the US Food and Drug Administration (FDA) in 2005 and by the European Medicines Agency (EMA) in 2006. Exenatide QW was approved by the FDA and EMA in 2012 and 2011 respectively. Liraglutide is a GLP-1RA, which, due to its $97 \%$ amino acid homology to native GLP-1, in contrast to exenatide, is a true GLP-1 analogue (Knudsen et al. 2000). Addition of a C16 fatty acid chain prolongs absorption from the subcutaneous depot and promotes albumin binding, collectively resulting in a prolonged $(13 \mathrm{~h})$ circulating half-life after s.c. injection. Consequently, liraglutide is suitable for QD administration. Liraglutide was approved in 2009 by the EMA and in 2010 by the FDA. Lixisenatide is a GLP-1RA based on exendin-4 that is DPP-4-resistant due to C-terminal modification with six lysine residues and deletion of one proline (Barnett 2011). Lixisenatide was approved by EMA in 2013 and will be submitted to the FDA in the near future. Although the half-life of lixisenatide is similar to that of exenatide BID, and lixisenatide is regarded as a short-acting GLP-1RA, it has fourfold higher affinity for the GLP-1 receptor than GLP-1 and therefore can be administered QD (Werner et al. 2010).

Short-acting GLP-1RA are more effective in lowering postprandial hyperglycaemia, while long-acting GLP-1RA rather reduce basal hyperglycaemia (Fineman et al. 2012). An important determinant of postprandial hyperglycaemia is the rate of gastric emptying. Rapid tachyphylaxis of gastric emptying deceleration, resulting from continuous stimulation of the GLP-1 receptor by long-acting (but not short-acting) GLP-1RA, may explain their lack of efficacy with respect to meal-related hyperglycaemia (Nauck et al. 2011). Inasmuch as gastric emptying delay also promotes the most common side effect of GLP-1RA, i.e. nausea and occasional vomiting, these side effects are more frequently observed with short-acting GLP-1RA than long-acting GLP-1RA (Drucker et al. 2008, Buse et al. 2009). The occurrence of these side effects may limit the possibility of higher dosing of GLP-1RA and possible greater improvement of glycaemic control and body weight reduction. The effects of GLP-1RA on gastric emptying and nausea and their possible influence on GLP-1RA-induced satiety will be discussed in more detail later in this review.

Several other GLP-1RA, mainly long-acting GLP-1RA, including albiglutide, semaglutide and dulaglutide are

Published by Bioscientifica Ltd 
currently under advanced clinical development (Fineman et al. 2012), but the preliminary clinical data are beyond the scope of this review.

\section{GLP-1RA and their effect on body weight}

GLP-1RA are approved for the treatment of T2DM because of their glucose-lowering effects. As an additional benefit, treatment with GLP-1RA is associated with sustained dosedependent weight lose. A meta-analysis of 21 trials (6411 participants) showed a weighted mean difference in body weight of $-2.9 \mathrm{~kg}(95 \% \mathrm{CI},-3.6$ to -2.2$)$ achieved with the highest dose of GLP-1RA compared with the control treatment (Vilsboll et al. 2012). Mean weight changes in trials comparing exenatide BID or liraglutide at the highest dose to placebo as add-on treatment to oral blood-glucoselowering agents during 20-30 weeks ranged from -3.1 to $-0.2 \mathrm{~kg}$ in the treatment group compared with -1.4 to + $0.6 \mathrm{~kg}$ in the placebo group (Table 1). In trials comparing exenatide BID, exenatide QW or liraglutide with basal or biphasic insulin, thus achieving similar glycaemic control in both intervention groups, the weight differences were even more prominent. Weight loss during GLP-1RA treatment ranged from 1.8 to $4.1 \mathrm{~kg}$, while weight gain with insulin therapy varied between 1.0 and $4.1 \mathrm{~kg}$ (Table 1). In phase-3 trials, weight loss effects of lixisenatide were relatively modest (up to a mean of $1.0 \mathrm{~kg}$ vs placebo; Petersen \& Christensen 2013; Table 1).

The observed GLP-1RA-related weight loss was associated with reduction in total body fat, particularly trunk or visceral fat (Jendle et al. 2009, Bunck et al. 2010). When on treatment, the achieved weight loss with GLP-1RA persisted over 52 weeks (Nauck et al. 2007, Bunck et al. 2009, Garber et al. 2009) and in open-label extension trials up to 2-3 years (Bunck et al. 2011, Garber et al. 2011, Macconell et al. 2013). Although open-label extension trials with GLP-1RA may be flawed by selection bias towards responders, the observed sustained weight loss over time seems different to weight loss through dietary restriction, where only a small minority of obese individuals maintain weight loss in the long term (Anderson et al. 2001). It is worthy of note, however, that when exenatide BID was discontinued after 3 years of exposure, patients started to regain weight during the 12 -week washout period (Bunck et al. 2011). Thus, no durable effects are present unless patients are on active GLP-1RA treatment.

In non-diabetic obese individuals, placebo-adjusted weight loss after 20-week treatment with liraglutide, at doses of 1.2, 1.8, 2.4 and 3.0 mg QD, ranged from a mean of $2.1-4.4 \mathrm{~kg}$, which persisted through 2 years of treatment
(Astrup et al. 2009, 2012). These seemingly more robust weight effects may be due to the higher doses of liraglutide used and higher BMI $\left(\sim 35 \mathrm{~kg} / \mathrm{m}^{2}\right)$ at baseline as compared with the phase- 3 trials in T2DM populations (BMI $\sim 32-33 \mathrm{~kg} / \mathrm{m}^{2}$ ). A small-sized study in severely obese non-diabetic individuals with impaired glucose metabolism (baseline BMI $\sim 40 \mathrm{~kg} / \mathrm{m}^{2}$ ) showed a mean placeboadjusted weight reduction of $3.3 \mathrm{~kg}$ after 24 weeks of exenatide $10 \mu \mathrm{g}$ BID (Rosenstock et al. 2010). It is worth noting that, currently, GLP-1RA have not been officially approved for the treatment of obesity.

Taking all these clinical results together, GLP-1RA are associated with weight loss. This has consistently been shown during treatment with short-acting and longacting GLP-1RA in both T2DM and obese individuals.

\section{Effects of GLP-1 and GLP-1RA on energy balance}

To attain body weight loss, achieving long-term negative energy balance by reduction in appetite and energy intake, or by an increase in energy expenditure or both is required.

Preclinical data indeed show an inhibiting effect of GLP-1 administration on food intake. Acute i.p. or s.c. administration of GLP-1 and exendin-4 resulted in a dosedependent inhibition of food intake in rodents (Rodriquez de Fonseca et al. 2000, Abbott et al. 2005, Talsania et al. 2005), which also persisted during prolonged administration of i.p. exendin-4 BID (Szayna et al. 2000). The reductions in food intake with GLP-1 and exendin- 4 are attributed to decreases in meal size (Scott \& Moran 2007, Ruttimann et al. 2009). However, GLP-1 infusion during a $3 \mathrm{~h}$ period reduced the cumulative food intake not only by reducing meal size but also meal frequency (Chelikani et al. 2005).

Also in humans, GLP-1 was shown to reduce food intake, appetite, and hunger and to promote fullness and satiety (Flint et al. 1998, 2001, Naslund et al. 1998, Gutzwiller et al. 1999, Verdich et al. 2001). It is noteworthy that satiation and satiety are commonly used as synonyms, but need to be distinguished (Mithieux 2013). Satiation is the increasing sensation of fullness that occurs during digestion and absorption of a meal. Satiety is a state of no-hunger that occurs some time after the last meal and moderates the initiation of the following meal. A placebocontrolled study in healthy normal-weight individuals investigating the effects of i.v. administration of GLP-1 during a $5 \mathrm{~h}$ period showed that GLP- 1 at pharmacological levels decreased hunger and enhanced satiety and fullness

Published by Bioscientifica Ltd 
Table 1 Weight changes during GLP-1RA treatment for 20-30 weeks compared with placebo or insulin. Weight changes from baseline to 20-30 weeks during phase-3 trials (no extension trials) comparing approved GLP-1RA with placebo or insulin in T2DM patients and obese (non-diabetic) individuals

\begin{tabular}{|c|c|c|c|c|c|c|}
\hline Study & $\begin{array}{c}\text { No. of } \\
\text { patients }\end{array}$ & $\begin{array}{l}\text { Duration } \\
\text { (weeks) }\end{array}$ & $\begin{array}{l}\text { Study } \\
\text { populations }\end{array}$ & Compound/dosing & $\begin{array}{l}\text { Mean (S.E.M.) } \\
\text { weight changes in } \\
\text { kg from baseline }\end{array}$ & $P$ value \\
\hline \multicolumn{7}{|c|}{ Add-on GLP-1RA treatment vs placebo } \\
\hline \multirow[t]{3}{*}{ Buse et al. (2004) } & 377 & 30 & T2DM & Exenatide $5 \mu \mathrm{g}$ BID & $-0.9(0.3)$ & NS \\
\hline & & & & Exenatide $10 \mu \mathrm{g}$ BID & $-1.6(0.3)$ & $<0.05$ \\
\hline & & & & Placebo & $-0.6(0.3)$ & - \\
\hline \multirow[t]{3}{*}{ DeFronzo et al. (2005) } & 137 & 30 & T2DM & Exenatide $5 \mu \mathrm{g}$ BID & $-1.6(0.4)$ & $<0.05$ \\
\hline & & & & Exenatide $10 \mu \mathrm{g}$ BID & $-2.8(0.5)$ & $<0.001$ \\
\hline & & & & Placebo & $-0.3(0.3)$ & - \\
\hline \multirow[t]{3}{*}{ Kendall et al. (2005) } & 733 & 30 & T2DM & Exenatide $5 \mu \mathrm{g}$ BID & $-1.6(0.2)$ & $<0.01$ \\
\hline & & & & Exenatide $10 \mu \mathrm{g}$ BID & $-1.6(0.2)$ & $<0.01$ \\
\hline & & & & Placebo & $-0.9(0.2)$ & - \\
\hline \multirow[t]{3}{*}{ Moretto et al. (2008) } & 232 & 24 & T2DM & Exenatide $5 \mu \mathrm{g}$ BID & $-2.8(0.3)$ & 0.004 \\
\hline & & & & Exenatide $10 \mu \mathrm{g}$ BID & $-3.1(0.3)$ & $<0.001$ \\
\hline & & & & Placebo & $-1.4(0.3)$ & - \\
\hline \multirow[t]{5}{*}{ Astrup et al. (2009) } & 371 & 24 & Obese, non-diabetic & Liraglutide $1.2 \mathrm{mg}$ QD & $-4.8(0.5)$ & 0.003 \\
\hline & & & & Liraglutide $1.8 \mathrm{mg}$ QD & $-5.5(0.5)$ & $<0.0001$ \\
\hline & & & & Liraglutide $2.4 \mathrm{mg}$ QD & $-6.3(0.5)$ & $<0.0001$ \\
\hline & & & & Liraglutide $3.0 \mathrm{mg}$ QD & $-7.2(0.5)$ & $<0.0001$ \\
\hline & & & & Placebo & $-2.8(0.5)$ & - \\
\hline \multirow[t]{4}{*}{ Marre et al. (2009) } & 1041 & 26 & T2DM & Liraglutide $0.6 \mathrm{mg}$ QD & $+0.7(0.0)$ & $<0.05$ \\
\hline & & & & Liraglutide $1.2 \mathrm{mg}$ QD & $+0.3(0.0)$ & NS \\
\hline & & & & Liraglutide $1.8 \mathrm{mg}$ QD & $-0.2(0.0)$ & $<0.05$ \\
\hline & & & & Placebo & $-0.1(0.1)$ & - \\
\hline \multirow[t]{4}{*}{ Nauck et al. (2009) } & 1091 & 26 & T2DM & Liraglutide $0.6 \mathrm{mg}$ QD & $-1.8(0.2)$ & NS \\
\hline & & & & Liraglutide $1.2 \mathrm{mg}$ QD & $-2.6(0.2)$ & $<0.01$ \\
\hline & & & & Liraglutide $1.8 \mathrm{mg}$ QD & $-2.8(0.2)$ & $<0.01$ \\
\hline & & & & Placebo & $-1.5(0.3)$ & - \\
\hline \multirow[t]{2}{*}{ Russell-Jones et al. (2009) } & 581 & 26 & T2DM & Liraglutide $1.8 \mathrm{mg}$ QD & $-1.8(0.3)$ & 0.0001 \\
\hline & & & & Placebo & $-0.4(0.4)$ & - \\
\hline \multirow[t]{3}{*}{ Zinman et al. (2009) } & 533 & 26 & T2DM & Liraglutide $1.2 \mathrm{mg}$ QD & $-1.0(0.3)$ & $<0.0001$ \\
\hline & & & & Liraglutide $1.8 \mathrm{mg}$ QD & $-2.0(0.3)$ & $<0.0001$ \\
\hline & & & & Placebo & $+0.6(0.3)$ & - \\
\hline \multirow[t]{2}{*}{ Rosenstock et al. (2010) } & 163 & 24 & Obese, non-diabetic & Exenatide $10 \mu \mathrm{g}$ BID & $-5.1(0.5)$ & $<0.001$ \\
\hline & & & & Placebo & $-1.6(0.5)$ & - \\
\hline \multirow[t]{2}{*}{ Bolli et al. (2011) } & 482 & 24 & T2DM & Lixisenatide $20 \mu \mathrm{g}$ QD & $-2.7(0.3)$ & 0.0025 \\
\hline & & & & Placebo & $-1.6(0.3)$ & - \\
\hline \multirow[t]{2}{*}{ Seino et al. (2012) ${ }^{a}$} & 311 & 24 & T2DM & Lixisenatide $20 \mu \mathrm{g}$ QD & $-0.4(0.3)$ & 0.086 \\
\hline & & & & Placebo & $+0.1(0.3)$ & - \\
\hline \multirow[t]{2}{*}{ Pinget et al. (2013) } & 484 & 24 & T2DM & Lixisenatide $20 \mu \mathrm{g}$ QD & $-0.2(0.3)$ & NS \\
\hline & & & & Placebo & $+0.2(0.3)$ & - \\
\hline \multirow[t]{2}{*}{ Riddle et al. (2013) ${ }^{a}$} & 446 & 24 & T2DM & Lixisenatide $20 \mu \mathrm{g}$ QD & $+0.3(0.3)$ & 0.0012 \\
\hline & & & & Placebo & $+1.2(0.3)$ & - \\
\hline \multicolumn{7}{|c|}{ Add on GLP-1RA vs insulin treatment } \\
\hline \multirow[t]{2}{*}{ Heine et al. (2005) } & 551 & 26 & T2DM & Exenatide $10 \mu \mathrm{g}$ BID & $-2.3(0.2)$ & $<0.0001$ \\
\hline & & & & Insulin glargine, titrated QD & $+1.8(0.2)$ & - \\
\hline \multirow[t]{3}{*}{ Bergenstal et al. (2009) } & 372 & 24 & T2DM & Exenatide $5 \mu \mathrm{g}$ BID & $-2.0(0.3)$ & $<0.001$ \\
\hline & & & & Insulin BIAsp 70/30 12 U QD & $+2.9(0.3)$ & - \\
\hline & & & & Insulin BIAsp 70/30 6 U BID & $+4.1(0.9)$ & - \\
\hline Davies et al. (2009) & 49 & 20 & T2DM & Exenatide $10 \mu \mathrm{g}$ BID & $-2.7(0.3)$ & $<0.001$ \\
\hline & & & & Insulin glargine, titrated QD & $+3.0(0.3)$ & - \\
\hline Russell-Jones et al. (2009) & 581 & 26 & T2DM & Liraglutide $1.8 \mathrm{mg}$ QD & $-1.8(0.3)$ & $<0.0001$ \\
\hline & & & & Insulin glargine, titrated QD & $+1.6(0.3)$ & - \\
\hline Diamant et al. (2010) & 456 & 26 & T2DM & Exenatide $2 \mathrm{mg} \mathrm{QW}$ & $-2.6(0.2)$ & $<0.05$ \\
\hline & & & & Insulin glargine, titrated QD & $+1.4(0.2)$ & - \\
\hline Gallwitz et al. (2011) & 363 & 26 & T2DM & Exenatide $10 \mu \mathrm{g}$ BID & $-4.1(0.2)$ & $<0.001$ \\
\hline & & & & Insulin BIAsp 70/30, titrated & $+1.0(0.2)$ & - \\
\hline
\end{tabular}

BIAsp, biphasic insulin aspart; BID, twice daily; NS, not significant; T2DM, type 2 diabetes mellitus; QD, once daily; QW, once weekly. ${ }^{a}$ These studies added GLP-1RA to insulin therapy. 
scores after an energy-fixed breakfast, measured by visual analogue scale (VAS) questionnaires, and reduced caloric intake by $12 \%$ during a subsequent ad libitum lunch (Flint et al. 1998). However, there were no differences in the subjective ratings of taste, visual appeal, smell, aftertaste and overall palatability of the meal. Similar reductions in hunger and increases in satiety scores were described in studies with a similar design in obese and T2DM individuals (Naslund et al. 1998, Gutzwiller et al. 1999). In a metaanalysis of studies in humans evaluating acute effects of GLP-1 infusion on food intake, a mean decrease of $11.7 \%$ was reported in the amount of ad libitum energy intake compared with saline (Verdich et al. 2001). Interestingly, reductions in VAS-score hunger ratings were not only present with pharmacological levels, but also with infusions attempting to achieve physiological postprandial GLP-1 levels ( $~ 50$ pmol/l; Flint et al. 2001). However, at the latter GLP-1 concentration, there were no statistically significant effects on ad libitum food intake.

Studies observing prolonged GLP-1 administration over more than one day are limited. Two small studies, using a continuous s.c. infusion pump, showed tendencies towards reduced hunger and enhanced fullness and satiety scores measured with VAS questionnaires. In a small study with six T2DM patients, GLP-1 administration over $48 \mathrm{~h}$ resulted in an average tendency towards a decrease in hunger and increase in satiety throughout the days, but this effect only reached statistical significance just before the start of the next meal (lunch and dinner; Toft-Nielsen et al. 1999). Furthermore, a hallmark proof-of-concept study, during which GLP-1 was administered via continuous s.c. infusion for 6 weeks in seven T2DM patients reported a trend towards reduction in overall appetite scores measured $2 \mathrm{~h}$ after the meal (Zander et al. 2001).

Taken together, these observations regarding food intake in humans show that GLP-1 administration has consistent acute effects on hunger, fullness and satiety measures. Longer-term studies in small groups indicate that a persistent reduction in appetite and food intake may mediate the effects of GLP-1RA treatment on body weight.

The body-weight-reducing effects of GLP-1RA treatment could also be due to increased energy expenditure, leading to a negative energy balance. However, the reported effects of GLP-1 on energy expenditure from animal data are not consistent. Energy expenditure depends on oxidation of substrates and consists of different elements, such as resting metabolic rate, physical activity and thermogenesis. Both i.v. and i.c.v. administration of GLP-1 in rats increased oxygen consumption, although the later had smaller effects (Hwa et al. 1998, Osaka et al. 2005), indicating that peripheral effects of GLP-1 are also important. In contrast, acute i.c.v. exendin4 administration in mice resulted in a rapid decrease in oxygen consumption (Baggio et al. 2004b), but vehicle administration also resulted in a large decrease in oxygen consumption, making the results difficult to interpret. Furthermore, 4 week i.c.v. treatment with a selective GLP-1 receptor antagonist (exendin 9-39) in mice resulted in a higher oxygen consumption $(\sim 22 \%)$ compared with vehicle, but the exendin 9-39-induced increase in food consumption ( $\sim 83 \%$ ) (Knauf et al. 2008) could contribute to the observed increase in oxygen consumption. More specifically, GLP-1 seems to affect thermogenesis. I.v. administration of GLP-1 in rats increased body temperature by $0.3{ }^{\circ} \mathrm{C}$. The effect of GLP- 1 on body temperature was not altered by decerebration, whereas cervical spinal transection attenuated the thermogenic response to GLP-1 (Osaka et al. 2005), indicating involvement of the lower brainstem but not forebrain areas in this mechanism. Moreover, i.c.v. GLP-1 administration in mice resulted in an increase in brown adipose tissue (BAT) thermogenesis (Lockie et al. 2012). Interestingly, BAT thermogenesis changes did correlate with an increased activity of sympathetic fibres innervating BAT. As peripherally administered GLP-1 did not alter BAT thermogenesis, it is likely that the thermogenic effects of GLP-1 are mediated by the brain. Taken together, these preclinical findings indicate that GLP-1 might have effects on the central regulation of energy balance by affecting energy expenditure and specifically thermogenesis, but the results are not fully conclusive.

In humans, the reported effects of GLP-1 on energy expenditure are more inconsistent. During acute GLP-1 infusion, energy expenditure caused by diet-induced thermogenesis was decreased in both healthy lean and obese individuals (Flint et al. 2000, 2001). After treatment of 4 weeks with liraglutide in T2DM patients, the estimated $24 \mathrm{~h}$ resting energy expenditure tended to increase (Horowitz et al. 2012), but this effect was not confirmed in trials with a treatment duration of 8-10 weeks with liraglutide or exenatide (Harder et al. 2004, Bradley et al. 2012).

Given the lack of consistency in the effects of GLP-1 and GLP-1RA on energy expenditure in humans, it has been concluded that the treatment-related body weight loss can rather be attributed to a decrease in energy intake. Various mechanisms and routes of action of GLP-1 are involved and contribute to the inhibitory effect on food intake.

Published by Bioscientifica Ltd 


\section{GLP-1 effects on the regulation of appetite: the role of delayed gastric emptying}

An important factor in the regulation of appetite and satiation during food intake is gastric mechanosensation. Distension of the stomach induces satiation signals by activation of gastric mechanoreceptors, which relay information via vagal nerves to the NTS in the brainstem. The amount of gastric distension due to food intake is partly influenced by the rate of gastric emptying, which affects postprandial glycaemic excursions. The role of gastric motility in appetite and satiation regulation and the effects of GLP-1/GLP-1RA on gastric and gut motility has been extensively reviewed (Janssen et al. 2011, Marathe et al. 2011). GLP-1 delays gastric emptying and gut motility not only in healthy lean but also in obese subjects and patients with T2DM (Nauck et al. 1997, Naslund et al. 1998, Schirra et al. 2002, Meier et al. 2003, Little et al. 2006). Delayed gastric emptying affects the extent of gastric distension, the rate of nutrient exposure of the gut and, consequently, gut hormones secretion, which in turn influences postprandial glucose excursions.

Although usually transient, gastrointestinal symptoms, most notably nausea and occasional vomiting, are the most commonly reported side effects during GLP-1RA treatment. One might speculate that changes in signalling due to delayed gastric emptying and nausea are the sole cause of GLP-1-induced changes in appetite and satiation and of GLP-1RA treatment-induced weight loss. In rodents, acute infusion with GLP-1RA induced a delay in gastric emptying, associated with a decrease in food intake. However, after 14 days of continuous GLP-1RA infusion, gastric emptying was similar to that of animals receiving a vehicle infusion, but food intake was still reduced (Jelsing et al. 2012). Also in humans, the inhibitory effect of GLP-1 on gastric emptying is subject to tachyphylaxis (Nauck et al. 2011). In spite of the observed tachyphylaxis of delayed gastric emptying, the weight-lowering effect of GLP-1RA treatment persists over periods up to 3 years (Macconell et al. 2013). Other observations making it less likely that GLP-1RA effects on gastric emptying are the only cause of appetite and weight loss include the observed weight reduction during GLP-1RA treatment in the absence of nausea (Buse et al. 2004, DeFronzo et al. 2005, Nauck et al. 2009, Russell-Jones et al. 2009, Garber et al. 2011, Shyangdan et al. 2011); similar or even greater weight loss with long-acting GLP-1RA, despite their reduced effect on gastric emptying relative to short-acting GLP-1RA (Jelsing et al. 2012); and the reported reduction in appetite after GLP-1 administration observed in fasting human subjects (with an empty stomach) (Gutzwiller et al. 1999). Taken together, other mechanisms than delayed gastric emptying alone contribute to the appetite-suppressing effect of GLP-1RA treatment. These effects may partly be mediated by actions of GLP-1 on CNS networks involved in the regulation of appetite.

\section{GLP-1 effects on the CNS regulation of appe- tite and satiety}

GLP-1/GLP-1RA exerts their effects on glucose homeostasis, feeding behaviour and body weight, both via direct and indirect pathways, which are largely mediated by the CNS (Fig. 1).

Experimental data indicate that GLP-1 may also exert actions in the brain beyond these well-established effects, by influencing neuronal health, cognition and neuroinflammation (During et al. 2003, Li et al. 2009, McClean et al. 2011, Tweedie et al. 2013). The latter CNS effects of GLP-1 are beyond the scope of this review.

A physiological role for GLP-1 in the central regulation of feeding was suggested when GLP-1 receptors were localised in many parts of the rat brain, including areas that are implicated in the control of food intake (including areas important for reward processing and motivated behaviour) and energy balance, such as the hypothalamus, NTS, AP, dorsal striatum and NAc (Shugrue et al. 1996, Merchenthaler et al. 1999). In addition, administration of GLP-1 into the lateral ventricle resulted in powerful inhibition of feeding when fasted male rats were refed, which was accompanied by $c$-Fos expression, a marker of neuronal activation, in both the paraventricular nucleus $(\mathrm{PVN})$ of the hypothalamus and the central nucleus of the amygdala (Turton et al. 1996). This effect was dosedependent and was blocked by i.c.v. administration of exendin 9-39, a highly selective antagonist of the GLP-1 receptor. Moreover, administration of GLP-1 into the third ventricle also significantly inhibited food intake in fasted male rats in a dose-dependent fashion (Schick et al. 2003). As i.c.v. GLP-1 administration in GLP-1 receptor knockout mice failed to reduce food intake, the GLP-1 receptor seems to be implicated in these GLP-1-induced effects. Interestingly, GLP-1-receptor deletion itself did not alter body weight or feeding behaviour (Scrocchi et al. 1996). Direct administration of GLP-1 into the PVN, lateral hypothalamus, dorsomedial hypothalamus and the ventromedial hypothalamus significantly reduced food intake, whereas injection of the GLP-1 receptor antagonist exendin 9-39 into the lateral hypothalamus augmented

Published by Bioscientifica Ltd 


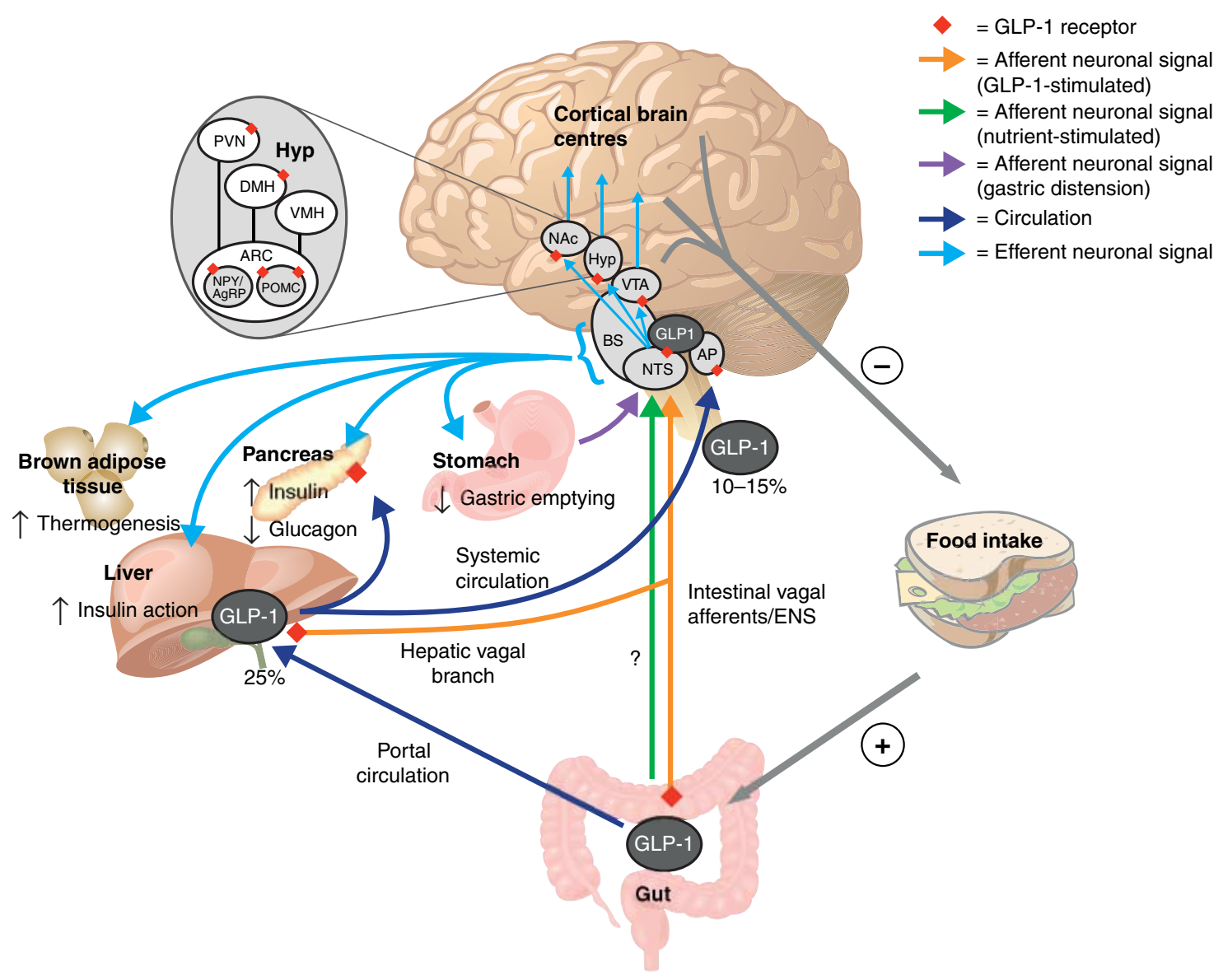

Figure 1

Proposed routes of action of GLP-1 in the central regulation of feeding and glucose metabolism. Gut-derived GLP-1 may affect the brain by several routes of action, i.e. indirectly, via neural afferents, and directly, by entering the brain via the systemic circulation and by crossing the blood-brain barrier. Other potential mediators constituting the gut-brain axis include nutrients and signals arising from meal-related gastric distension. GLP-1 secreted from intestinal L-cells in response to meal-ingestion, diffuses across the basal lamina into the lamina propria, at which level the uptake by capillaries and the degradation by DPP-4 occurs. Subsequently, endogenous GLP-1 activates intestinal vagal afferents, located in the gut or portal circulation, partly belonging to the enteric nervous system (ENS), which may activate GLP-1-producing neurons in the nucleus tractus solitarii (NTS). Additional activation of intestinal or portal vagal afferents by nutrients, other gut-hormones or gastric distension may also activate these GLP-1-producing neurons. These neurons project to several foodregulating areas, most of which contain GLP-1 receptors. These areas include the ventral tegmental area (VTA), the nucleus accumbens (NAC) and the hypothalamus (Hyp). Throughout the hypothalamus, the GLP-1 receptor is present, particularly in the paraventricular nucleus (PVN), dorsomedial hypothalamus $(\mathrm{DMH})$ and the arcuate nucleus (ARC), with a greater density on pro-opiomelanocortin (POMC) neurons (anorexigenic neurons) than on the agouti-related peptide (AgRP)/neuropeptide Y (NPY) neurons (orexigenic neurons). To date, no receptors have been found in the ventromedial hypothalamus (VMH). Less is known about the higher cortical centres that extend the circuitry beyond the hypothalamus, VTA and nucleus accumbens. Only $25 \%$ of the gut-derived GLP-1 reaches the portal circulation, where it can activate afferent hepatic vagal nerves, while merely $10-15 \%$ of gut-derived GLP-1 enters the systemic circulation and may access the brain through areas with a permeable blood-brain barrier, such as the area postrema (AP) and ARC. Efferent pathways, among others, originating in the brain stem (BS), subsequently signal to peripheral organs to close the loop of feeding behaviour and glucose metabolism regulation, both of which may be partly interlinked. Accordingly, GLP-1 lowers blood glucose by stimulating pancreatic insulin secretion and production, and by suppressing glucagon secretion from the pancreas and by enhancing hepatic insulin action in a glucose-dependent manner. Also, GLP-1-related effects promoting gastric emptying delay seem to be part of this regulatory loop. These actions may be due to direct effects of circulating gutderived GLP-1 but, given the short circulating half-life of the incretin hormone, indirect, neurally mediated effects may contribute, even to a greater extent, to the efferent output to these organs.

food intake in satiated rats. Despite the reported presence of GLP-1 receptors, injections of GLP-1 directly into the ARC did not affect food intake (Sandoval et al. 2008). The effects of GLP-1 on food intake may not only be due to effects on hypothalamic and brainstem circuits regulating homeostatic feeding, but also due to effects on the rewarding value of food that are exerted at the level of the mesolimbic reward system. Microinfusion of exendin4 in key mesolimbic structures, ventral tegmental area and NAc, resulted in decreased motivated behaviour for

Published by Bioscientifica Ltd 
sucrose in rats (Dickson et al. 2012). Also, injection of exendin 9-39 into the NAc resulted in significant hyperphagia in rats, indicating a physiologic role of GLP-1 receptors in the NAc for the control of food intake (Dossat et al. 2011). Collectively, these preclinical data show that central GLP-1 induces satiety by affecting both homeostatic and reward-associated food intake and that these effects seem to be GLP-1 receptor-mediated.

\section{Routes of action of GLP-1: direct and indirect effects on the CNS}

The inhibitory effects of GLP-1 on food intake may be due to both direct and indirect effects on the CNS (Fig. 1), but the exact routes of action are largely unknown. Gut-derived GLP-1 may enter the brain through the AP, at the level of which the blood-brain barrier is permeable. A radiolabelled GLP-1 analogue has been demonstrated to easily cross the blood-brain barrier in mice (Kastin et al. 2002). But due to its short circulating half-life (Kieffer et al. 1995), it is likely that only a small amount of gut-derived GLP-1 reaches the brain. Therefore, it is unclear whether peripherally released GLP-1 needs to enter the brain to affect food intake, or whether other routes of action are involved in its effects on feeding behaviour. Based on in situ hybridisation experiments, preproglucagon-encoding mRNA was found in a single population of neurons in the caudal portion of the NTS, indicating that local GLP-1 synthesis in the brainstem which could serve to amplify peripherally generated GLP-1 signals (Larsen et al. 1997). However, more recent work has shown that after i.p. administration of exendin-4 in male rats the majority of GLP-1-containing neurons in the NTS were not c-Fos-positive (Gu et al. 2013). Interestingly, i.p. administration of exendin-4 resulted in extensive $c$-Fos expression in regions where a high density of GLP-1immunoreactive terminals originating from the NTS were localised. Therefore, it remains undetermined whether the GLP-1-containing neurons in the NTS have a role in amplifying or relaying gut-derived GLP-1 signals to the central GLP-1 networks.

The relative importance of peripheral vs central GLP-1 networks for control of satiety was studied in mice by acute peripheral and central administration of exendin- 4 and the large GLP-1-albumin fusion protein albiglutide (Albugon), which is unable to cross the blood-brain barrier (Baggio et al. 2004a). Exendin-4 and albiglutide both reduced glycaemic excursions, which inhibited food intake and gastric emptying after peripheral as well as i.c.v. administration. Albiglutide, injected i.p., was more effective in lowering hyperglycaemia than inducing satiety. Although c-Fos activation in different CNS nuclei was similar after peripheral albiglutide administration, it was less robust compared with the pattern induced by exendin- 4 . These experiments indicated that both peripheral and central mechanisms are involved in the GLP-1 receptor-mediated effects on glucose and energy homeostasis.

Studies using the GLP-1 receptor antagonist exendin 939 provide further insights into the routes of action of GLP-1. Peripheral administration of exendin 9-39 increased food intake when given to satiated rats (Williams et al. 2009). To differentiate between central and peripheral pathways involved, exendin 9-39 was injected either centrally or peripherally before both central and peripheral injection of GLP-1. Anorexia induced by peripheral GLP-1 was totally blocked by peripheral, but not central i.c.v. pretreatment with exendin 9-39, whereas the opposite was true for the anorectic effect of central GLP-1, which was not blocked by peripheral exendin 9-39. These data indicate that GLP-1 released by the intestine acts as a physiological satiety signal by activating peripheral GLP-1 receptors, whereas central GLP-1 affects feeding through GLP-1 receptors in the brain. Interestingly, these findings also imply that the anorectic effects of peripheral GLP-1 do not depend on central GLP-1 receptors. However, given the previously mentioned data, it seems likely that the GLP-1 systems in the CNS and in the periphery work together in the regulation of feeding behaviour.

Because GLP-1 receptors have been observed on vagal fibres (Vahl et al. 2007), it has been suggested that the vagal nerve plays an important role in the communication between gut and brain. This hypothesis was supported by experiments with vagotomised animals. The effects of i.p. injected GLP-1 on food intake and activation of hypothalamic ARC feeding neurons were abolished after bilateral subdiaphragmatic total truncal vagotomy as well as after brainstem-hypothalamic pathway transectioning in rats (Abbott et al. 2005). However, these experiments did not allow the identification of the exact portion of the vagal nerve (intestinal or hepatic) involved in the GLP-1-mediated effects. Gut-derived GLP-1 diffuses across the basal lamina of the gut into the lamina propria, where the uptake by capillaries and the degradation by DPP- 4 take place. Only $25 \%$ of the gut-derived GLP-1 reaches the portal circulation and $10-15 \%$ of the secreted amount leaves the liver and enters the systemic circulation (Holst \& Deacon 2005). As the portal circulation has the highest GLP-1 levels, vagal afferents in the portal branch may be an

Published by Bioscientifica Ltd 
important site of action of GLP-1. Indeed, intraportal infusion of DPP-4 inhibitor was shown to suppress food intake in rats and to increase c-Fos expression in several areas of the brain and these responses were blocked by hepatic vagotomy (Fujiwara et al. 2012). Moreover, it was shown that food intake suppression induced by i.p. GLP-1 was blunted in rats with complete subdiaphragmatic vagal deafferentation, but not in rats with selective ablation of the common hepatic branch of the vagal nerve (Hayes et al. 2011). These results unlike that the hepatic branch of the vagus is not the only route via which GLP-1 induces effects on food intake. There may be paracrine-like GLP-1 signalling on GLP-1 receptors expressed on vagal afferents innervating the gastrointestinal tract and actions of GLP-1 in the portal area as well as on gastrointestinal vagal afferents may reduce food intake. Recently, truncally vagotomised male subjects showed no reduction in ad libitum food intake during exogenous i.v. GLP-1 administration, unlike healthy control subjects (Plamboeck et al. 2013). Similar to rodents, these findings indicate an involvement of vagal afferent signalling in peripheral GLP-1-mediated regulation of feeding in humans.

In conclusion, effects of GLP-1 in the CNS may be due to both direct and indirect routes of action. However, it seems that GLP-1 more probably exerts its actions on the brain by indirect pathways, i.e. via vagal afferents originating in the intestine and portal circulation. However, additional information regarding the interaction between the various circuits involved is needed in future studies.

\section{GLP-1 effects on food-related brain responses; neuroimaging studies}

With the development of neuroimaging techniques, recent studies substantiate the effects of GLP-1 on brain areas related to feeding, in both animals but particularly in humans in vivo. An observational study using ${ }^{15} \mathrm{O}$-water PET for cerebral blood flow (CBF) measurement showed that the postprandial increase in GLP-1 concentration correlated with the postprandial regional CBF increments in the hypothalamus and left dorsolateral prefrontal cortex (Pannacciulli et al. 2007). Using ${ }^{18}$ FDG PET, GLP-1 infusion in lean individuals reduced glucose metabolism in the hypothalamus and brainstem (Alvarez et al. 2005). These findings demonstrate that exogenous GLP-1 is associated with altered cerebral glucose metabolism, but the relationship of these cerebral changes with food intake and appetite is not clear.
Functional magnetic resonance imaging (fMRI) is currently used to assess neuronal activation in a resting state, but also in response to different tasks or stimuli. Intragastric nutrient infusion in male rats reduced fMRImeasured activation in homeostatic (hypothalamus and NTS) and non-homeostatic (cortico-limbic) brain areas and these effects were inversely correlated with circulating GLP-1 plasma concentrations (Min et al. 2011). Injection of GLP-1 i.p. into fasted mice reduced fMRI signal intensity in the PVN, increased signal intensity in the $\mathrm{VMH}$ and resulted in no alterations in the ARC. Ad libitum fed rats (without exogenous GLP-1 administration) also showed a reduced activation in the PVN, but as well as in the ARC, and elicited no changes in the VMH (Chaudhri et al. 2006). Taken together, this indicates that feedinginduced changes in PVN activity may be related to GLP-1. Ad libitum feeding resulted in a decrease in ARC signal intensity that could not be replicated by exogenous GLP-1 infusions, indicating that changes in ARC activity during feeding probably result from other signals than GLP-1.

The effects of GLP-1 infusion on fMRI-measured neuronal activity have also been studied in humans (DeSilva et al. 2011). In healthy normal-weight individuals (11 males and five females), the mean fMRI signal change was described in a priori selected brain regions involved in reward processing and hedonic feeding (dorsal striatum, NAc, insula, amygdala and orbitofrontal cortex). Mean activity in these regions was attenuated when viewing food pictures in the fed as compared with the fasted state. Interestingly, GLP-1 infusion in the fasted state attenuated neuronal activity to an extent similar to that observed after feeding. The effect of exenatide vs saline infusion on hypothalamic connectivity was studied using fMRI in obese males and 'responders' (i.e. those who showed reduction in ad libitum food intake after exenatide infusion) vs 'non-responders' were compared (Schlogl et al. 2013). During scanning, different pictures (food and nonfood) were presented and subjects were asked to rate the pictures for tastiness. While rating the food pictures, only the group of responders showed a higher connectivity of the hypothalamus during exenatide infusion compared with placebo. Connectivity is a proxy for the influence of this brain region on the rest of the brain. The effect of exenatide on connectivity was not observed in the non-responder group nor in the responder group while rating non-food pictures, supporting the hypothesis of a hypothalamic exenatide effect specific to states when networks of appetite and feeding control are active.

Taken together, these studies indicate that peripherally administered GLP-1 affects brain activity in areas

Published by Bioscientifica Ltd

Downloaded from Bioscientifica.com at $04 / 25 / 2023$ 11:21:45PM via free access 
involved in the regulation of feeding. These effects could contribute to the appetite-suppressing effect of GLP-1 and the weight loss during GLP-1RA treatment.

\section{Conclusions}

Different signals from peripheral organs convey different aspects of nutritional status to the CNS. In the search of treatments for obesity, the potential therapeutic utility of these peripheral signals has been explored, but with no success. GLP-1RA are currently employed in the treatment of patients with T2DM and, in addition to their glucoselowering effect, have shown consistent body weight loss in the majority of patients. These weight effects seem to be the result of combined central and peripheral actions of GLP-1RA, collectively promoting satiety, decreasing hunger sensation and ultimately leading to reductions in food intake. Possibly, GLP-1RA-induced deceleration of gastric emptying and occasional nausea could contribute to the weight reducing effects, but seem to play a minor and often temporary role. GLP-1/GLP-1RA-mediated inhibition of food intake was attributed to its direct central actions, based on the presence of GLP-1 receptors in brain regions implicated in the control of food intake and energy balance, the observations that GLP-1 and some GLP-1RA can cross the blood-brain barrier, and studies showing that i.c.v. administration of GLP-1 reduced food intake in rodents. However, currently, it seems that in addition to direct CNS effects of GLP-1, the incretin more probably exerts its actions on the brain by indirect pathways, i.e. via vagal afferents originating in the intestine and portal circulation. To date, it is unclear whether the GLP-1-producing neurons in the NTS, potentially acting to modify or amplify peripheral signals to the brain, that were previously described in rodents, also exist in humans. The role of this pathway and its interactions with the direct and indirect GLP-1 signalling circuits require extensive study to advance our understanding in the mechanisms underlying GLP-1-mediated regulation of feeding behaviour. State-of-the-art neuroimaging techniques have recently been employed which may help to further our knowledge of this field. Using PET and particularly fMRI, effects of peripherally injected GLP1 on brain activity and connectivity of areas involved in the regulation of feeding could be demonstrated. Future research should determine which routes of action are involved in the effects of endogenous meal-related GLP-1 (physiology) as well as the actions of exogenously administered GLP-1RA (pharmacology) on the CNS to regulate feeding behaviour and body weight in humans.
These investigations may help to identify targets for future development of preventive and therapeutic strategies for the 'diabesity' pandemic.

\section{Declaration of interest}

Dr M D is a consultant for Abbott, Astra Zeneca, Bristol-Myers Squibb (BMS), Boehringer-Ingelheim, Eli Lilly, GI Dynamics, Inc., Merck Sharp \& Dohme (MSD), Novo Nordisk, Poxel Pharma and Sanofi; and a speaker for BMS/Astra Zeneca, Eli Lilly, Novo Nordisk and Sanofi. Through Dr M D, the VU University Medical Center received research grants from Abbott, BMS-Astra, Boehringer-Ingelheim, Eli Lilly, Medtronic, MSD, Novo Nordisk and Sanofi. Dr M D reports receiving no personal payments in connection to the above-mentioned activities, but all payments are directly transferred to the Diabetes Centre non-profit Research Foundation.

\section{Funding}

This review did not receive any specific grant from any funding agency in the public, commercial or not-for-profit sector.

\section{References}

Abbott CR, Monteiro M, Small CJ, Sajedi A, Smith KL, Parkinson JR, Ghatei MA \& Bloom SR 2005 The inhibitory effects of peripheral administration of peptide YY(3-36) and glucagon-like peptide-1 on food intake are attenuated by ablation of the vagal-brainstemhypothalamic pathway. Brain Research 1044 127-131. (doi:10.1016/ j.brainres.2005.03.011)

Alvarez E, Martinez MD, Roncero I, Chowen JA, Garcia-Cuartero B, Gispert JD, Sanz C, Vazquez P, Maldonado A, de Cáceres J et al. 2005 The expression of GLP-1 receptor mRNA and protein allows the effect of GLP-1 on glucose metabolism in the human hypothalamus and brainstem. Journal of Neurochemistry 92 798-806. (doi:10.1111/ j.1471-4159.2004.02914.x)

Anderson JW, Konz EC, Frederich RC \& Wood CL 2001 Long-term weightloss maintenance: a meta-analysis of US studies. American Journal of Clinical Nutrition 74 579-584.

Anthony K, Reed LJ, Dunn JT, Bingham E, Hopkins D, Marsden PK \& Amiel SA 2006 Attenuation of insulin-evoked responses in brain networks controlling appetite and reward in insulin resistance: the cerebral basis for impaired control of food intake in metabolic syndrome? Diabetes 55 2986-2992. (doi:10.2337/db06-0376)

Astrup A, Rossner S, Van Gaal L, Rissanen A, Niskanen L, Al Hakim M, Madsen J, Rasmussen MF \& Lean ME 2009 Effects of liraglutide in the treatment of obesity: a randomised, double-blind, placebo-controlled study. Lancet 374 1606-1616. (doi:10.1016/S0140-6736(09)61375-1)

Astrup A, Carraro R, Finer N, Harper A, Kunesova M, Lean M, Niskanen L, Rasmussen M, Rissanen A, Rossner S et al. 2012 Safety, tolerability and sustained weight loss over 2 years with the once-daily human GLP-1 analog, liraglutide. International Journal of Obesity 36 843-854. (doi:10.1038/ijo.2011.158)

Baggio LL \& Drucker DJ 2004 Clinical endocrinology and metabolism. Glucagon-like peptide-1 and glucagon-like peptide-2. Best Practice \& Research. Clinical Endocrinology \& Metabolism 18 531-554. (doi:10.1016/ j.beem.2004.08.001)

Baggio LL, Huang Q, Brown TJ \& Drucker DJ 2004a A recombinant human glucagon-like peptide (GLP)-1-albumin protein (Albugon) mimics peptidergic activation of GLP-1 receptor-dependent pathways coupled with satiety, gastrointestinal motility, and glucose homeostasis. Diabetes 53 2492-2500. (doi:10.2337/diabetes.53.9.2492) 
Baggio LL, Huang Q, Brown TJ \& Drucker DJ 2004b Oxyntomodulin and glucagon-like peptide-1 differentially regulate murine food intake and energy expenditure. Gastroenterology 127 546-558. (doi:10.1053/ j.gastro.2004.04.063)

Bailey EF 2008 A tasty morsel: the role of the dorsal vagal complex in the regulation of food intake and swallowing. Focus on "BDNF/TrkB signaling interacts with GABAergic system to inhibit rhythmic swallowing in the rat," by Bariohay et al. American Journal of Physiology. Regulatory, Integrative and Comparative Physiology 295 R1048-R1049. (doi:10.1152/ajpregu.90701.2008)

Barnett AH 2011 Lixisenatide: evidence for its potential use in the treatment of type 2 diabetes. Core Evidence 6 67-79. (doi:10.2147/ CE.S15525)

Benedict C, Kern W, Schultes B, Born J \& Hallschmid M 2008 Differential sensitivity of men and women to anorexigenic and memory-improving effects of intranasal insulin. Journal of Clinical Endocrinology and Metabolism 93 1339-1344. (doi:10.1210/jc.2007-2606)

Bergenstal R, Lewin A, Bailey T, Chang D, Gylvin T \& Roberts V 2009 Efficacy and safety of biphasic insulin aspart 70/30 versus exenatide in subjects with type 2 diabetes failing to achieve glycemic control with metformin and a sulfonylurea. Current Medical Research and Opinion 25 65-75. (doi:10.1185/03007990802597951)

Berthoud HR 2011 Metabolic and hedonic drives in the neural control of appetite: who is the boss? Current Opinion in Neurobiology 21 888-896. (doi:10.1016/j.conb.2011.09.004)

Bolli G, Munteanu M, Dotsenko S, Niemoeller E, Boka G \& Hanefeld M 2011 Efficacy and safety of lixisenatide once-daily versus placebo in patients with type 2 diabetes mellitus insufficiently controlled on metformin (GetGoal-F1). Diabetologia 54 S316.

Bradley DP, Kulstad R, Racine N, Shenker Y, Meredith M \& Schoeller DA 2012 Alterations in energy balance following exenatide administration. Applied Physiology, Nutrition, and Metabolism 37 893-899. (doi:10.1139/ h2012-068)

Bruning JC, Gautam D, Burks DJ, Gillette J, Schubert M, Orban PC, Klein R, Krone W, Muller-Wieland D \& Kahn CR 2000 Role of brain insulin receptor in control of body weight and reproduction. Science 289 2122-2125. (doi:10.1126/science.289.5487.2122)

Bunck MC, Diamant M, Corner A, Eliasson B, Malloy JL, Shaginian RM, Deng W, Kendall DM, Taskinen MR, Smith U et al. 2009 One-year treatment with exenatide improves $\beta$-cell function, compared with insulin glargine, in metformin-treated type 2 diabetic patients: a randomized, controlled trial. Diabetes Care 32 762-768. (doi:10.2337/ dc08-1797)

Bunck MC, Diamant M, Eliasson B, Corner A, Shaginian RM, Heine RJ, Taskinen MR, Yki-Jarvinen H \& Smith U 2010 Exenatide affects circulating cardiovascular risk biomarkers independently of changes in body composition. Diabetes Care 33 1734-1737. (doi:10.2337/dc09-2361)

Bunck MC, Corner A, Eliasson B, Heine RJ, Shaginian RM, Taskinen MR, Smith U, Yki-Jarvinen H \& Diamant M 2011 Effects of exenatide on measures of $\beta$-cell function after 3 years in metformin-treated patients with type 2 diabetes. Diabetes Care 34 2041-2047. (doi:10.2337/dc11-0291)

Buse JB, Henry RR, Han J, Kim DD, Fineman MS \& Baron AD 2004 Effects of exenatide (exendin-4) on glycemic control over 30 weeks in sulfonylurea-treated patients with type 2 diabetes. Diabetes Care 27 2628-2635. (doi:10.2337/diacare.27.11.2628)

Buse JB, Rosenstock J, Sesti G, Schmidt WE, Montanya E, Brett JH, Zychma M \& Blonde L 2009 Liraglutide once a day versus exenatide twice a day for type 2 diabetes: a 26-week randomised, parallel-group, multinational, open-label trial (LEAD-6). Lancet 374 39-47. (doi:10.1016/S01406736(09)60659-0)

Chaudhri OB, Parkinson JR, Kuo YT, Druce MR, Herlihy AH, BellJD, Dhillo WS, Stanley SA, Ghatei MA \& Bloom SR 2006 Differential hypothalamic neuronal activation following peripheral injection of GLP-1 and oxyntomodulin in mice detected by manganese-enhanced magnetic resonance imaging. Biochemical and Biophysical Research Communications 350 298-306. (doi:10.1016/j.bbrc.2006.09.033)

Chelikani PK, Haver AC \& Reidelberger RD 2005 Intravenous infusion of glucagon-like peptide-1 potently inhibits food intake, sham feeding, and gastric emptying in rats. American Journal of Physiology. Regulatory, Integrative and Comparative Physiology 288 R1695-R1706. (doi:10.1152/ ajpregu.00870.2004)

Cohen P, Zhao C, Cai X, Montez JM, Rohani SC, Feinstein P, Mombaerts P $\&$ Friedman JM 2001 Selective deletion of leptin receptor in neurons leads to obesity. Journal of Clinical Investigation 108 1113-1121. (doi:10.1172/JCI13914)

Considine RV, Sinha MK, Heiman ML, Kriauciunas A, Stephens TW, Nyce MR, Ohannesian JP, Marco CC, McKee LJ \& Bauer TL 1996 Serum immunoreactive-leptin concentrations in normal-weight and obese humans. New England Journal of Medicine 334 292-295. (doi:10.1056/ NEJM199602013340503)

Costantini VJ, Vicentini E, Sabbatini FM, Valerio E, Lepore S, Tessari M, Sartori M, Michielin F, Melotto S, Bifone A et al. 2011 GSK1614343, a novel ghrelin receptor antagonist, produces an unexpected increase of food intake and body weight in rodents and dogs. Neuroendocrinology 94 158-168. (doi:10.1159/000328968)

Crawley JN \& Beinfeld MC 1983 Rapid development of tolerance to the behavioural actions of cholecystokinin. Nature 302 703-706. (doi:10.1038/302703a0)

Cummings BP 2013 Leptin therapy in type 2 diabetes. Diabetes, Obesity \& Metabolism 15 607-612. (doi:10.1111/dom.12048)

Davies MJ, Donnelly R, Barnett AH, Jones S, Nicolay C \& Kilcoyne A 2009 Exenatide compared with long-acting insulin to achieve glycaemic control with minimal weight gain in patients with type 2 diabetes: results of the Helping Evaluate Exenatide in patients with diabetes compared with Long-Acting insulin (HEELA) study. Diabetes, Obesity \& Metabolism 11 1153-1162. (doi:10.1111/j.1463-1326.2009.01154.x)

DeFronzo RA, Ratner RE, Han J, Kim DD, Fineman MS \& Baron AD 2005 Effects of exenatide (exendin-4) on glycemic control and weight over 30 weeks in metformin-treated patients with type 2 diabetes. Diabetes Care 28 1092-1100. (doi:10.2337/diacare.28.5.1092)

DeSilva A, Salem V, Long CJ, Makwana A, Newbould RD, Rabiner EA, Ghatei MA, Bloom SR, Matthews PM, Beaver JD et al. 2011 The gut hormones PYY 3-36 and GLP-1 7-36 amide reduce food intake and modulate brain activity in appetite centers in humans. Cell Metabolism 14 700-706. (doi:10.1016/j.cmet.2011.09.010)

Diamant M, Van Gaal L, Stranks S, Northrup J, Cao D, Taylor K \& Trautmann M 2010 Once weekly exenatide compared with insulin glargine titrated to target in patients with type 2 diabetes (DURATION-3): an open-label randomised trial. Lancet 375 2234-2243. (doi:10.1016/S0140-6736(10) 60406-0)

Dickson SL, Shirazi RH, Hansson C, Bergquist F, Nissbrandt H \& Skibicka KP 2012 The glucagon-like peptide 1 (GLP-1) analogue, exendin-4, decreases the rewarding value of food: a new role for mesolimbic GLP-1 receptors. Journal of Neuroscience 32 4812-4820. (doi:10.1523/JNEUROSCI.6326-11.2012)

Dossat AM, Lilly N, Kay K \& Williams DL 2011 Glucagon-like peptide 1 receptors in nucleus accumbens affect food intake. Journal of Neuroscience 31 14453-14457. (doi:10.1523/JNEUROSCI.3262-11.2011)

Drucker DJ 2006 The biology of incretin hormones. Cell Metabolism 3 153-165. (doi:10.1016/j.cmet.2006.01.004)

Drucker DJ \& Nauck MA 2006 The incretin system: glucagon-like peptide-1 receptor agonists and dipeptidyl peptidase-4 inhibitors in type 2 diabetes. Lancet 368 1696-1705. (doi:10.1016/S0140-6736(06)69705-5)

Drucker DJ, Philippe J, Mojsov S, Chick WL \& Habener JF 1987 Glucagonlike peptide I stimulates insulin gene expression and increases cyclic AMP levels in a rat islet cell line. PNAS 84 3434-3438. (doi:10.1073/ pnas.84.10.3434)

Drucker DJ, Buse JB, Taylor K, Kendall DM, Trautmann M, Zhuang D \& Porter L 2008 Exenatide once weekly versus twice daily for the

Published by Bioscientifica Ltd 
treatment of type 2 diabetes: a randomised, open-label, non-inferiority study. Lancet 372 1240-1250. (doi:10.1016/S0140-6736(08)61206-4)

During MJ, Cao L, Zuzga DS, Francis JS, Fitzsimons HL, Jiao X, Bland RJ, Klugmann M, Banks WA, Drucker DJ et al. 2003 Glucagon-like peptide-1 receptor is involved in learning and neuroprotection. Nature Medicine 9 1173-1179. (doi:10.1038/nm919)

Enriori PJ, Evans AE, Sinnayah P, Jobst EE, Tonelli-Lemos L, Billes SK, Glavas MM, Grayson BE, Perello M, Nillni EA et al. 2007 Diet-induced obesity causes severe but reversible leptin resistance in arcuate melanocortin neurons. Cell Metabolism 5 181-194. (doi:10.1016/j.cmet.2007.02.004)

Field AE, Coakley EH, Must A, Spadano JL, Laird N, Dietz WH, Rimm E \& Colditz GA 2001 Impact of overweight on the risk of developing common chronic diseases during a 10-year period. Archives of Internal Medicine 161 1581-1586. (doi:10.1001/archinte.161.13.1581)

Fineman MS, Cirincione BB, Maggs D \& Diamant M 2012 GLP-1 based therapies: differential effects on fasting and postprandial glucose. Diabetes, Obesity \& Metabolism 14 675-688. (doi:10.1111/j.1463-1326. 2012.01560.x)

Flegal KM, Carroll MD, Kit BK \& Ogden CL 2012 Prevalence of obesity and trends in the distribution of body mass index among US adults, 1999-2010. Journal of the American Medical Association 307 491-497. (doi:10.1001/jama.2012.39)

Flint A, Raben A, Astrup A \& Holst JJ 1998 Glucagon-like peptide 1 promotes satiety and suppresses energy intake in humans. Journal of Clinical Investigation 101 515-520. (doi:10.1172/JCI990)

Flint A, Raben A, Rehfeld JF, Holst JJ \& Astrup A 2000 The effect of glucagon-like peptide-1 on energy expenditure and substrate metabolism in humans. International Journal of Obesity and Related Metabolic Disorders 24 288-298. (doi:10.1038/sj.ijo.0801126)

Flint A, Raben A, Ersboll AK, Holst JJ \& Astrup A 2001 The effect of physiological levels of glucagon-like peptide- 1 on appetite, gastric emptying, energy and substrate metabolism in obesity. International Journal of Obesity and Related Metabolic Disorders 25 781-792. (doi:10.1038/sj.ijo.0801627)

Fujiwara K, Gotoh K, Chiba S, Masaki T, Katsuragi I, Kakuma T \& Yoshimatsu H 2012 Intraportal administration of DPP-IV inhibitor regulates insulin secretion and food intake mediated by the hepatic vagal afferent nerve in rats. Journal of Neurochemistry 121 66-76. (doi:10.1111/j.1471-4159.2011.07563.x)

Gallwitz B, Bohmer M, Segiet T, Molle A, Milek K, Becker B, Helsberg K, Petto H, Peters N \& Bachmann O 2011 Exenatide twice daily versus premixed insulin aspart 70/30 in metformin-treated patients with type 2 diabetes: a randomized 26-week study on glycemic control and hypoglycemia. Diabetes Care 34 604-606. (doi:10.2337/dc10-1900)

Gao Q \& Horvath TL 2008 Neuronal control of energy homeostasis. FEBS Letters 582 132-141. (doi:10.1016/j.febslet.2007.11.063)

Garber A, Henry R, Ratner R, Garcia-Hernandez PA, Rodriguez-Pattzi H, Olvera-Alvarez I, Hale PM, Zdravkovic M \& Bode B 2009 Liraglutide versus glimepiride monotherapy for type 2 diabetes (LEAD-3 Mono): a randomised, 52-week, phase III, double-blind, parallel-treatment trial. Lancet 373 473-481. (doi:10.1016/S0140-6736(08)61246-5)

Garber A, Henry RR, Ratner R, Hale P, Chang CT \& Bode B 2011 Liraglutide, a once-daily human glucagon-like peptide 1 analogue, provides sustained improvements in glycaemic control and weight for 2 years as monotherapy compared with glimepiride in patients with type 2 diabetes. Diabetes, Obesity \& Metabolism 13 348-356. (doi:10.1111/ j.1463-1326.2010.01356.x)

van Genugten RE, van Raalte DH \& Diamant M 2009 Does glucagon-like peptide- 1 receptor agonist therapy add value in the treatment of type 2 diabetes? Focus on exenatide Diabetes Research and Clinical Practice 86(Suppl 1) S26-S34. (doi:10.1016/S0168-8227(09)70006-3)

Gu G, Roland B, Tomaselli K, Dolman CS, Lowe C \& Heilig JS 2013 Glucagon-like peptide- 1 in the rat brain: distribution of expression and functional implication. Journal of Comparative Neurology $\mathbf{5 2 1}$ 2235-2261. (doi:10.1002/cne.23282)
Gutzwiller JP, Drewe J, Goke B, Schmidt H, Rohrer B, Lareida J \& Beglinger C 1999 Glucagon-like peptide-1 promotes satiety and reduces food intake in patients with diabetes mellitus type 2. American Journal of Physiology 276 R1541-R1544.

Harder H, Nielsen L, Tu DT \& Astrup A 2004 The effect of liraglutide, a longacting glucagon-like peptide 1 derivative, on glycemic control, body composition, and 24-h energy expenditure in patients with type 2 diabetes. Diabetes Care 27 1915-1921. (doi:10.2337/diacare.27.8.1915)

Havel PJ 2001 Peripheral signals conveying metabolic information to the brain: short-term and long-term regulation of food intake and energy homeostasis. Experimental Biology and Medicine 226 963-977.

Hayes MR, Kanoski SE, De Jonghe BC, Leichner TM, Alhadeff AL, Fortin SM, Arnold M, Langhans W \& Grill HJ 2011 The common hepatic branch of the vagus is not required to mediate the glycemic and food intake suppressive effects of glucagon-like-peptide-1. American Journal of Physiology. Regulatory, Integrative and Comparative Physiology 301 R1479-R1485. (doi:10.1152/ajpregu.00356.2011)

Heine RJ, Van Gaal LF, Johns D, Mihm MJ, Widel MH \& Brodows RG 2005 Exenatide versus insulin glargine in patients with suboptimally controlled type 2 diabetes: a randomized trial. Annals of Internal Medicine $\mathbf{1 4 3}$ 559-569. (doi:10.7326/0003-4819-143-8-200510180-00006)

Holst JJ 2007 The physiology of glucagon-like peptide 1. Physiological Reviews 87 1409-1439. (doi:10.1152/physrev.00034.2006)

Holst JJ \& Deacon CF 2005 Glucagon-like peptide-1 mediates the therapeutic actions of DPP-IV inhibitors. Diabetologia 48 612-615. (doi:10.1007/s00125-005-1705-7)

Holz GG, Kuhtreiber WM \& Habener JF 1993 Pancreatic $\beta$-cells are rendered glucose-competent by the insulinotropic hormone glucagon-like peptide-1(7-37). Nature 361 362-365. (doi:10.1038/361362a0)

Horowitz M, Flint A, Jones KL, Hindsberger C, Rasmussen MF, Kapitza C, Doran S, Jax T, Zdravkovic M \& Chapman IM 2012 Effect of the once-daily human GLP-1 analogue liraglutide on appetite, energy intake, energy expenditure and gastric emptying in type 2 diabetes. Diabetes Research and Clinical Practice 97 258-266. (doi:10.1016/j.diabres.2012.02.016)

Hwa JJ, Ghibaudi L, Williams P, Witten MB, Tedesco R \& Strader CD 1998 Differential effects of intracerebroventricular glucagon-like peptide-1 on feeding and energy expenditure regulation. Peptides 19 869-875. (doi:10.1016/S0196-9781(98)00033-3)

Janssen P, Vanden BP, Verschueren S, Lehmann A, Depoortere I \& Tack J 2011 Review article: The role of gastric motility in the control of food intake. Alimentary Pharmacology \& Therapeutics 33 880-894. (doi:10.1111/j.1365-2036.2011.04609.x)

Jelsing J, Vrang N, Hansen G, Raun K, Tang-Christensen M \& Knudsen LB 2012 Liraglutide: short-lived effect on gastric emptying-long lasting effects on body weight. Diabetes, Obesity \& Metabolism 14 531-538. (doi:10.1111/j.1463-1326.2012.01557.x)

Jendle J, Nauck MA, Matthews DR, Frid A, Hermansen K, During M, Zdravkovic M, Strauss BJ \& Garber AJ 2009 Weight loss with liraglutide, a once-daily human glucagon-like peptide- 1 analogue for type 2 diabetes treatment as monotherapy or added to metformin, is primarily as a result of a reduction in fat tissue. Diabetes, Obesity \& Metabolism 11 1163-1172. (doi:10.1111/j.1463-1326.2009.01158.x)

Jordan J, Greenway FL, Leiter LA, Li Z, Jacobson P, Murphy K, Hill J, Kler L \& Aftring RP 2008 Stimulation of cholecystokinin-A receptors with GI181771X does not cause weight loss in overweight or obese patients. Clinical Pharmacology and Therapeutics 83 281-287. (doi:10.1038/sj.clpt.6100272)

Kastin AJ, Akerstrom V \& Pan W 2002 Interactions of glucagon-like peptide-1 (GLP-1) with the blood-brain barrier. Journal of Molecular Neuroscience 18 7-14. (doi:10.1385/JMN:18:1-2:07)

Kendall DM, Riddle MC, Rosenstock J, Zhuang D, Kim DD, Fineman MS \& Baron AD 2005 Effects of exenatide (exendin-4) on glycemic control over 30 weeks in patients with type 2 diabetes treated with metformin and a sulfonylurea. Diabetes Care 28 1083-1091. (doi:10.2337/diacare.28.5.1083)

Kenny PJ 2011 Reward mechanisms in obesity: new insights and future directions. Neuron 69 664-679. (doi:10.1016/j.neuron.2011.02.016) 
Kieffer TJ, McIntosh CH \& Pederson RA 1995 Degradation of glucosedependent insulinotropic polypeptide and truncated glucagon-like peptide 1 in vitro and in vivo by dipeptidyl peptidase IV. Endocrinology 136 3585-3596. (doi:10.1210/en.136.8.3585)

Knauf C, Cani PD, Ait-Belgnaoui A, Benani A, Dray C, Cabou C, Colom A, Uldry M, Rastrelli S, Sabatier E et al. 2008 Brain glucagon-like peptide 1 signaling controls the onset of high-fat diet-induced insulin resistance and reduces energy expenditure. Endocrinology 149 4768-4777. (doi:10.1210/en.2008-0180)

Knudsen LB, Nielsen PF, Huusfeldt PO, Johansen NL, Madsen K, Pedersen FZ, Thogersen H, Wilken M \& Agerso H 2000 Potent derivatives of glucagonlike peptide-1 with pharmacokinetic properties suitable for once daily administration. Journal of Medicinal Chemistry 43 1664-1669. (doi:10.1021/jm9909645)

Kreymann B, Williams G, Ghatei MA \& Bloom SR 1987 Glucagon-like peptide-1 7-36: a physiological incretin in man. Lancet 2 1300-1304. (doi:10.1016/S0140-6736(87)91194-9)

Larsen PJ, Tang-Christensen M, Holst JJ \& Orskov C 1997 Distribution of glucagon-like peptide-1 and other preproglucagon-derived peptides in the rat hypothalamus and brainstem. Neuroscience 77 257-270. (doi:10.1016/S0306-4522(96)00434-4)

Levin BE \& Dunn-Meynell AA 2002 Reduced central leptin sensitivity in rats with diet-induced obesity. American Journal of Physiology. Regulatory, Integrative and Comparative Physiology 283 R941-R948. (doi:10.1152/ ajpregu.00245.2002)

Li Y, Perry T, Kindy MS, Harvey BK, Tweedie D, Holloway HW, Powers K, Shen H, Egan JM, Sambamurti K et al. 2009 GLP-1 receptor stimulation preserves primary cortical and dopaminergic neurons in cellular and rodent models of stroke and Parkinsonism. PNAS 106 1285-1290. (doi:10.1073/pnas.0806720106)

Little TJ, Pilichiewicz AN, Russo A, Phillips L, Jones KL, Nauck MA, Wishart J, Horowitz M \& Feinle-Bisset C 2006 Effects of intravenous glucagon-like peptide- 1 on gastric emptying and intragastric distribution in healthy subjects: relationships with postprandial glycemic and insulinemic responses. Journal of Clinical Endocrinology and Metabolism 91 1916-1923. (doi:10.1210/jc.2005-2220)

Lockie SH, Heppner KM, Chaudhary N, Chabenne JR, Morgan DA, VeyratDurebex C, Ananthakrishnan G, Rohner-Jeanrenaud F, Drucker DJ, DiMarchi R et al. 2012 Direct control of brown adipose tissue thermogenesis by central nervous system glucagon-like peptide-1 receptor signaling. Diabetes 61 2753-2762. (doi:10.2337/db11-1556)

Lutter M \& Nestler EJ 2009 Homeostatic and hedonic signals interact in the regulation of food intake. Journal of Nutrition 139 629-632. (doi:10.3945/jn.108.097618)

Macconell L, Pencek R, Li Y, Maggs D \& Porter L 2013 Exenatide once weekly: sustained improvement in glycemic control and cardiometabolic measures through 3 years. Diabetes, Metabolic Syndrome and Obesity: Targets and Therapy 6 31-41. (doi:10.2147/DMSO.S35801)

Marathe CS, Rayner CK, Jones KL \& Horowitz M 2011 Effects of GLP-1 and incretin-based therapies on gastrointestinal motor function. Experimental Diabetes Research 2011 279530. (doi:10.1155/2011/279530)

Marre M, Shaw J, Brandle M, Bebakar WM, Kamaruddin NA, Strand J, Zdravkovic M, Le Thi TD \& Colagiuri S 2009 Liraglutide, a once-daily human GLP-1 analogue, added to a sulphonylurea over 26 weeks produces greater improvements in glycaemic and weight control compared with adding rosiglitazone or placebo in subjects with type 2 diabetes (LEAD-1 SU). Diabetic Medicine 26 268-278. (doi:10.1111/ j.1464-5491.2009.02666.x)

McClean PL, Parthsarathy V, Faivre E \& Holscher C 2011 The diabetes drug liraglutide prevents degenerative processes in a mouse model of Alzheimer's disease. Journal of Neuroscience 31 6587-6594. (doi:10.1523/JNEUROSCI.0529-11.2011)

Meier JJ, Gallwitz B, Salmen S, Goetze O, Holst JJ, Schmidt WE \& Nauck MA 2003 Normalization of glucose concentrations and deceleration of gastric emptying after solid meals during intravenous glucagon-like peptide 1 in patients with type 2 diabetes. Journal of Clinical Endocrinology and Metabolism 88 2719-2725. (doi:10.1210/jc.2003-030049)

Merchenthaler I, Lane M \& Shughrue P 1999 Distribution of pre-proglucagon and glucagon-like peptide-1 receptor messenger RNAs in the rat central nervous system. Journal of Comparative Neurology $\mathbf{4 0 3}$ 261-280. (doi:10.1002/(SICI)1096-9861(19990111)403:2\%3C;261:: AID-CNE8\%3E;3.0.CO;2-5)

Min DK, Tuor UI, Koopmans HS \& Chelikani PK 2011 Changes in differential functional magnetic resonance signals in the rodent brain elicited by mixed-nutrient or protein-enriched meals. Gastroenterology 141 1832-1841. (doi:10.1053/j.gastro.2011.07.034)

Mithieux G 2013 Nutrient control of hunger by extrinsic gastrointestinal neurons. Trends in Endocrinology and Metabolism 24 378-384. (doi:10.1016/j.tem.2013.04.005)

Mojsov S, Weir GC \& Habener JF 1987 Insulinotropin: glucagon-like peptide I (7-37) co-encoded in the glucagon gene is a potent stimulator of insulin release in the perfused rat pancreas. Journal of Clinical Investigation 79 616-619. (doi:10.1172/JCI112855)

Moon HS, Chamberland JP, Diakopoulos KN, Fiorenza CG, Ziemke F, Schneider B \& Mantzoros CS 2011 Leptin and amylin act in an additive manner to activate overlapping signaling pathways in peripheral tissues: in vitro and ex vivo studies in humans. Diabetes Care 34 132-138. (doi:10.2337/dc10-0518)

Moretto TJ, Milton DR, Ridge TD, Macconell LA, Okerson T, Wolka AM \& Brodows RG 2008 Efficacy and tolerability of exenatide monotherapy over 24 weeks in antidiabetic drug-naive patients with type 2 diabetes: a randomized, double-blind, placebo-controlled, parallelgroup study. Clinical Therapeutics 30 1448-1460. (doi:10.1016/ j.clinthera.2008.08.006)

Naslund E, Gutniak M, Skogar S, Rossner S \& Hellstrom PM 1998 Glucagonlike peptide 1 increases the period of postprandial satiety and slows gastric emptying in obese men. American Journal of Clinical Nutrition 68 525-530.

Nauck MA, Niedereichholz U, Ettler R, Holst JJ, Orskov C, Ritzel R \& Schmiegel WH 1997 Glucagon-like peptide 1 inhibition of gastric emptying outweighs its insulinotropic effects in healthy humans. American Journal of Physiology 273 E981-E988.

Nauck MA, Duran S, Kim D, Johns D, Northrup J, Festa A, Brodows R \& Trautmann M 2007 A comparison of twice-daily exenatide and biphasic insulin aspart in patients with type 2 diabetes who were suboptimally controlled with sulfonylurea and metformin: a non-inferiority study. Diabetologia 50 259-267. (doi:10.1007/s00125-006-0510-2)

Nauck M, Frid A, Hermansen K, Shah NS, Tankova T, Mitha IH, Zdravkovic M, During M \& Matthews DR 2009 Efficacy and safety comparison of liraglutide, glimepiride, and placebo, all in combination with metformin, in type 2 diabetes: the LEAD (liraglutide effect and action in diabetes)-2 study. Diabetes Care 32 84-90. (doi:10.2337/dc08-1355)

Nauck MA, Kemmeries G, Holst JJ \& Meier JJ 2011 Rapid tachyphylaxis of the glucagon-like peptide 1-induced deceleration of gastric emptying in humans. Diabetes 60 1561-1565. (doi:10.2337/db10-0474)

Nielsen LL, Young AA \& Parkes DG 2004 Pharmacology of exenatide (synthetic exendin-4): a potential therapeutic for improved glycemic control of type 2 diabetes. Regulatory Peptides 117 77-88. (doi:10.1016/j. regpep.2003.10.028)

Osaka T, Endo M, Yamakawa M \& Inoue S 2005 Energy expenditure by intravenous administration of glucagon-like peptide- 1 mediated by the lower brainstem and sympathoadrenal system. Peptides 26 1623-1631. (doi:10.1016/j.peptides.2005.02.016)

Pannacciulli N, Le DS, Salbe AD, Chen K, Reiman EM, Tataranni PA \& Krakoff J 2007 Postprandial glucagon-like peptide-1 (GLP-1) response is positively associated with changes in neuronal activity of brain areas implicated in satiety and food intake regulation in humans. NeuroImage 35 511-517. (doi:10.1016/j.neuroimage.2006.12.035)

Petersen AB \& Christensen M 2013 Clinical potential of lixisenatide once daily treatment for type 2 diabetes mellitus. Diabetes, Metabolic 
Syndrome and Obesity: Targets and Therapy 6 217-231. (doi:10.2147/ DMSO.S45379)

Pinget M, Goldenberg R, Niemoeller E, Muehlen-Bartmer I, Guo H \& Aronson R 2013 Efficacy and safety of lixisenatide once daily versus placebo in type 2 diabetes insufficiently controlled on pioglitazone (GetGoal-P). Diabetes, Obesity \& Metabolism 15 1000-1007. (doi:10.1111/dom.12121)

Plamboeck A, Veedfald S, Deacon CF, Hartmann B, Wettergren A, Svendsen LB, Meisner S, Hovendahl C, Vilsboll T, Knop FK et al. 2013 The effect of exogenous GLP-1 on food intake is lost in male truncally vagotomized subjects with pyloroplasty. American Journal of Physiology. Gastrointestinal and Liver Physiology 304 G1117-G1127. (doi:10.1152/ajpgi.00035. 2013)

Polonsky KS, Given BD \& Van Cauter E 1988 Twenty-four-hour profiles and pulsatile patterns of insulin secretion in normal and obese subjects. Journal of Clinical Investigation 81 442-448. (doi:10.1172/JCI113339)

Raufman JP, Singh L, Singh G \& EngJ 1992 Truncated glucagon-like peptide-1 interacts with exendin receptors on dispersed acini from guinea pig pancreas. Identification of a mammalian analogue of the reptilian peptide exendin-4. Journal of Biological Chemistry $26721432-21437$.

Riddle MC, Forst T, Aronson R, Sauque-Reyna L, Souhami E, Silvestre L, Ping L \& Rosenstock J 2013 Adding once-daily lixisenatide for type 2 diabetes inadequately controlled with newly initiated and continuously titrated basal insulin glargine: a 24-week, randomized, placebo-controlled study (GetGoal-Duo 1). Diabetes Care.

Rodriquez de Fonseca F, Navarro M, Alvarez E, Roncero I, Chowen JA, Maestre O, Gomez R, Munoz RM, Eng J \& Blazquez E 2000 Peripheral versus central effects of glucagon-like peptide-1 receptor agonists on satiety and body weight loss in Zucker obese rats. Metabolism 49709 717. (doi:10.1053/meta.2000.6251)

Rosenstock J, Klaff LJ, Schwartz S, Northrup J, Holcombe JH, Wilhelm K \& Trautmann M 2010 Effects of exenatide and lifestyle modification on body weight and glucose tolerance in obese subjects with and without pre-diabetes. Diabetes Care 33 1173-1175. (doi:10.2337/dc09-1203)

Russell-Jones D, Vaag A, Schmitz O, Sethi BK, Lalic N, Antic S, Zdravkovic M, Ravn GM \& Simo R 2009 Liraglutide vs insulin glargine and placebo in combination with metformin and sulfonylurea therapy in type 2 diabetes mellitus (LEAD-5 met +SU): a randomised controlled trial. Diabetologia 52 2046-2055. (doi:10.1007/s00125-009-1472-y)

Ruttimann EB, Arnold M, Hillebrand JJ, Geary N \& Langhans W 2009 Intrameal hepatic portal and intraperitoneal infusions of glucagon-like peptide-1 reduce spontaneous meal size in the rat via different mechanisms. Endocrinology 150 1174-1181. (doi:10.1210/en.2008-1221)

Sandoval DA, Bagnol D, Woods SC, D’Alessio DA \& Seeley RJ 2008 Arcuate glucagon-like peptide 1 receptors regulate glucose homeostasis but not food intake. Diabetes 57 2046-2054. (doi:10.2337/db07-1824)

Schick RR, Zimmermann JP, vorm Walde T \& Schusdziarra V 2003 Peptides that regulate food intake: glucagon-like peptide 1-(7-36) amide acts at lateral and medial hypothalamic sites to suppress feeding in rats. American Journal of Physiology. Regulatory, Integrative and Comparative Physiology 284 R1427-R1435. (doi:10.1152/ajpregu.00479.2002)

Schirra J, Wank U, Arnold R, Goke B \& Katschinski M 2002 Effects of glucagonlike peptide-1(7-36)amide on motility and sensation of the proximal stomach in humans. Gut 50 341-348. (doi:10.1136/gut.50.3.341)

Schlogl H, Kabisch S, Horstmann A, Lohmann G, Muller K, Lepsien J, BusseVoigt F, Kratzsch J, Pleger B, Villringer A et al. 2013 Exenatide-induced reduction in energy intake is associated with increase in hypothalamic connectivity. Diabetes Care 36 1933-1940. (doi:10.2337/dc12-1925)

Schwartz MW, Woods SC, Porte D Jr, Seeley RJ \& Baskin DG 2000 Central nervous system control of food intake. Nature $\mathbf{4 0 4}$ 661-671. (doi:10.1038/35007534)

Scott KA \& Moran TH 2007 The GLP-1 agonist exendin-4 reduces food intake in nonhuman primates through changes in meal size. American Journal of Physiology. Regulatory, Integrative and Comparative Physiology 293 R983-R987. (doi:10.1152/ajpregu.00323.2007)
Scrocchi LA, Brown TJ, MaClusky N, Brubaker PL, Auerbach AB, Joyner AL \& Drucker DJ 1996 Glucose intolerance but normal satiety in mice with a null mutation in the glucagon-like peptide 1 receptor gene. Nature Medicine 2 1254-1258. (doi:10.1038/nm1196-1254)

Seino Y, Min KW, Niemoeller E \& Takami A 2012 Randomized, doubleblind, placebo-controlled trial of the once-daily GLP-1 receptor agonist lixisenatide in Asian patients with type 2 diabetes insufficiently controlled on basal insulin with or without a sulfonylurea (GetGoalL-Asia). Diabetes, Obesity \& Metabolism 14 910-917. (doi:10.1111/ j.1463-1326.2012.01618.x)

Shugrue PJ, Lane M \& Merchenthaler I 1996 Glucagon-like peptide-1 receptor (GLP1-R) mRNA in the rat hypothalamus. Endocrinology 137 5159-5162. (doi:10.1210/en.137.11.5159)

Shyangdan DS, Royle P, Clar C, Sharma P, Waugh N \& Snaith A 2011 Glucagon-like peptide analogues for type 2 diabetes mellitus. Cochrane Database of Systematic Reviews 10 CD006423. (doi:10.1002/14651858. CD006423.pub2)

Sivertsen J, Rosenmeier J, Holst JJ \& Vilsboll T 2012 The effect of glucagonlike peptide 1 on cardiovascular risk. Nature Reviews. Cardiology 9 209-222. (doi:10.1038/nrcardio.2011.211)

Stratton IM, Adler AI, Neil HA, Matthews DR, Manley SE, Cull CA, Hadden D, Turner RC \& Holman RR 2000 Association of glycaemia with macrovascular and microvascular complications of type 2 diabetes (UKPDS 35): prospective observational study. BMJ 321 405-412. (doi:10.1136/ bmj.321.7258.405)

Szayna M, Doyle ME, Betkey JA, Holloway HW, Spencer RG, Greig NH \& Egan JM 2000 Exendin-4 decelerates food intake, weight gain, and fat deposition in Zucker rats. Endocrinology 141 1936-1941. (doi:10.1210/ en.141.6.1936)

Talsania T, Anini Y, Siu S, Drucker DJ \& Brubaker PL 2005 Peripheral exendin-4 and peptide YY(3-36) synergistically reduce food intake through different mechanisms in mice. Endocrinology 146 3748-3756. (doi:10.1210/en.2005-0473)

Toft-Nielsen MB, Madsbad S \& Holst JJ 1999 Continuous subcutaneous infusion of glucagon-like peptide 1 lowers plasma glucose and reduces appetite in type 2 diabetic patients. Diabetes Care 22 1137-1143. (doi:10.2337/diacare.22.7.1137)

Trinko R, Sears RM, Guarnieri DJ \& DiLeone RJ 2007 Neural mechanisms underlying obesity and drug addiction. Physiology \& Behavior 91 499-505. (doi:10.1016/j.physbeh.2007.01.001)

Turton MD, O'Shea D, Gunn I, Beak SA, Edwards CM, Meeran K, Choi SJ, Taylor GM, Heath MM, Lambert PD et al. 1996 A role for glucagon-like peptide- 1 in the central regulation of feeding. Nature 379 69-72. (doi:10.1038/379069a0)

Tweedie D, Rachmany L, Rubovitch V, Lehrmann E, Zhang Y, Becker KG, Perez E, Miller J, Hoffer BJ, Greig NH et al. 2013 Exendin-4, a glucagonlike peptide-1 receptor agonist prevents mTBI-induced changes in hippocampus gene expression and memory deficits in mice. Experimental Neurology 239 170-182. (doi:10.1016/j.expneurol.2012.10.001)

Vahl TP, Tauchi M, Durler TS, Elfers EE, Fernandes TM, Bitner RD, Ellis KS, Woods SC, Seeley RJ, Herman JP et al. 2007 Glucagon-like peptide-1 (GLP-1) receptors expressed on nerve terminals in the portal vein mediate the effects of endogenous GLP-1 on glucose tolerance in rats. Endocrinology 148 4965-4973. (doi:10.1210/en.2006-0153)

Verdich C, Flint A, Gutzwiller JP, Naslund E, Beglinger C, Hellstrom PM, Long SJ, Morgan LM, Holst JJ \& Astrup A 2001 A meta-analysis of the effect of glucagon-like peptide-1 (7-36) amide on ad libitum energy intake in humans. Journal of Clinical Endocrinology and Metabolism 86 4382-4389. (doi:10.1210/jc.86.9.4382)

Vilsboll T \& Garber AJ 2012 Non-glycaemic effects mediated via GLP-1 receptor agonists and the potential for exploiting these for therapeutic benefit: focus on liraglutide. Diabetes, Obesity \& Metabolism 14(Suppl 2) 41-49. (doi:10.1111/j.1463-1326.2012.01579.x)

Vilsboll T, Christensen M, Junker AE, Knop FK \& Gluud LL 2012 Effects of glucagon-like peptide-1 receptor agonists on weight loss: systematic

Published by Bioscientifica Ltd 
review and meta-analyses of randomised controlled trials. BMJ 344 d7771. (doi:10.1136/bmj.d7771)

Volkow ND \& Wise RA 2005 How can drug addiction help us understand obesity? Nature Neuroscience 8 555-560. (doi:10.1038/nn1452)

Wang GJ, Volkow ND, Thanos PK \& Fowler JS 2004 Similarity between obesity and drug addiction as assessed by neurofunctional imaging: a concept review. Journal of Addictive Diseases 23 39-53. (doi:10.1300/ J069v23n03_04)

Werner U, Haschke G, Herling AW \& Kramer W 2010 Pharmacological profile of lixisenatide: a new GLP-1 receptor agonist for the treatment of type 2 diabetes. Regulatory Peptides 164 58-64. (doi:10.1016/j.regpep.2010.05.008)

Whiting DR, Guariguata L, Weil C \& Shaw J 2011 IDF diabetes atlas: global estimates of the prevalence of diabetes for 2011 and 2030. Diabetes Research and Clinical Practice 94 311-321. (doi:10.1016/j.diabres.2011.10.029)

Williams DL, Baskin DG \& Schwartz MW 2009 Evidence that intestinal glucagon-like peptide-1 plays a physiological role in satiety. Endocrinology 150 1680-1687. (doi:10.1210/en.2008-1045)
Woods SC, Lotter EC, McKay LD \& Porte D Jr 1979 Chronic intracerebroventricular infusion of insulin reduces food intake and body weight of baboons. Nature 282 503-505. (doi:10.1038/282503a0)

Young AA, Gedulin BR, Bhavsar S, Bodkin N, Jodka C, Hansen B \& Denaro M 1999 Glucose-lowering and insulin-sensitizing actions of exendin-4: studies in obese diabetic $(o b / o b, d b / d b)$ mice, diabetic fatty Zucker rats, and diabetic rhesus monkeys (Macaca mulatta). Diabetes $\mathbf{4 8}$ 1026-1034. (doi:10.2337/diabetes.48.5.1026)

Zander M, Taskiran M, Toft-Nielsen MB, Madsbad S \& Holst JJ 2001 Additive glucose-lowering effects of glucagon-like peptide-1 and metformin in type 2 diabetes. Diabetes Care 24 720-725. (doi:10.2337/ diacare.24.4.720)

Zinman B, Gerich J, Buse JB, Lewin A, Schwartz S, Raskin P, Hale PM, Zdravkovic M \& Blonde L 2009 Efficacy and safety of the human glucagonlike peptide- 1 analog liraglutide in combination with metformin and thiazolidinedione in patients with type 2 diabetes (LEAD-4 Met +TZD). Diabetes Care 32 1224-1230. (doi:10.2337/dc08-2124)

Received in final form 28 November 2013

Accepted 9 December 2013

Accepted Preprint published online 9 December 2013
C 2014 Society for Endocrinology Printed in Great Britain
Published by Bioscientifica Ltd 